KOŚCIÓŁ I PRAWO 10(23) 2021, nr 2, s. 67-84

DOI: https://doi.org/10.18290/kip21102.4

Tomasz Gałkowski

DEFINIOWANIE PRAWA KANONICZNEGO

WPROWADZENIE

Rynek wydawniczy w Polsce w ostatnim czasie zaobfitował kilkoma publikacjami o charakterze encyklopedycznym poświęconym zagadnieniom prawa, w tym również kanonicznego: Wielka Encyklopedia Prawa [Smoktunowicz i Kosikowski 2000], Stownik Prawa Kanonicznego [Sitarz 2004], Wielka Encyklopedia Prawa (t. 2: Prawo Kanoniczne) [Leszczyński 2014], Leksykon Prawa Kanonicznego [Sitarz 2019]. W tytule zawierają charakterystyczne dla takich form publikacji sformułowania: encyklopedia, leksykon, słownik, które narzucają przedstawienie poszczególnych zagadnień w przyjętej formie. Forma, bardziej niż treść, stanowią element jednoczący poszczególne opracowania. Natomiast treść w znacznej mierze uzależniona jest od preferencji naukowych osób, które przedstawiają w miarę zwięźle i jednocześnie zrozumiale poszczególne zagadnienia. Z takim podejściem wiąże się konieczność dokonywania wyborów, co w znacznej mierze wpływa również na merytoryczne ograniczenie przedstawianego zagadnienia. W miarę pełen obraz może dać spojrzenie na konkretne zagadnienie jednocześnie przedstawione w kilku publikacjach. Stanowią one bowiem niejako początek w poszukiwaniu wiadomości czy elementów wiedzy na dany temat. Wiedza w zakresie nauk społecznych, do których w Polsce zostały zaliczone nauki prawne, jest intelektualnie obszerna i dopuszczająca różne

DR HAB. Tomasz GaŁKOWSKI CP, PROF. UKSW - Katedra Historii, Teorii i Norm Ogólnych Prawa Kanonicznego, Wydział Prawa Kanonicznego, Uniwersytet Kardynała Stefana Wyszyńskiego w Warszawie; adres do korespondencji: ul. Dewajtis 5, 01-815 Warszawa, Polska; e-mail: t.galkowski@uksw.edu.pl; https://orcid.org/0000-0001-9166-9516 
sposoby rozumowania i argumentacji, o ile zawierają się $\mathrm{w}$ ramach uzasadnionych metod naukowego podejścia. Z tego też względu ograniczenie się czasami jedynie do jednego opracowania może spotkać się z niezrozumieniem czy nawet negacją. Nie umniejsza to jednak wartości zawartym w tychże publikacjach podstawowym informacjom. I jako podstawowe, a nie wyczerpujące należałoby je traktować nie zapominając, że metodologia pracy naukowej warunkuje przedstawione osiągnięcia i wyniki.

Opracowane i przedstawione „hasła” są wynikiem wiedzy, ale wskazują również na preferencje i orientacje badawcze ich autorów. Na ich podstawie można wnioskować o takich preferencjach, co nie jest jednoznaczne z wykluczeniem przez nich wiedzy będącej wynikiem innych podejść i preferencji. $\mathrm{Z}$ taką sytuacją mamy do czynienia w przypadku hasła „prawo kanoniczne", które jest motywem wiodącym niniejszego opracowania. Zapoznanie się z tym samym hasłem w kolejnych publikacjach skutkuje dla mniej zaznajomionych z problematyką poczucia niejednoznaczności treści, a z drugiej strony dla bardziej wymagających może być wskazówką ogromu materiału, z którym mamy do czynienia wchodząc w obszar prawnego wymiaru Kościoła.

Analizując poszczególne publikacje, które pojawiły się na polskim rynku wydawniczym zatrzymam się jedynie na haśle „prawo kanoniczne” i wskażę na treści w nim zawarte obrazujące rozumienie tego obszaru w życiu Kościoła i pewne orientacje w podejściu do badań nad prawem kanonicznym. W dalszej części zwrócę uwagę na trudności związane z próbami i możliwościami zdefiniowania prawa kanonicznego. Ciekawe jest również spojrzenie i rozumienie prawa kanonicznego, które zostało zaprezentowane w opracowaniach spoza kręgu kanonistyki, w ramach wiedzy o prawie.

\section{ENCYKLOPEDIE, SŁOWNIKI, LEKSYKONY}

Pomimo, iż publikacje, w których zostało zaprezentowane znaczenie pojęcia „prawo kanoniczne” zwierają podobny sposób jego prezentacji - krótko, zasadniczo, w miarę treściwie - to jednak określenie charakteru publikacji powinno determinować sposób prezentacji poszczególnych haseł. Zastosowanie się do kryteriów oceny zawartych w charakterze publikacji może również mieć wpływ na przedstawione treści, co warto mieć przed oczyma, gdy sięga się po krótkie i wygodne opracowanie. Czy zatem treść 
poszczególnych opracowań tego samego pojęcia (hasła) odzwierciedla założenia wydawnicze zakreślone charakterem opracowania? Spróbujmy odpowiedzieć sięgając do poszczególnych określeń wydawniczych.

Pojęcie „leksykon” obejmuje swym znaczeniem ogólnie słownictwo w znaczeniu zasobu słów. W odniesieniu do nazwy wydawnictwa książkowego posiada znaczenie równoznaczne pojęciu „encyklopedia”, „słownik” [Bańko 2005, 327]. „Leksykon prawa kanonicznego” jako wydanie książkowe oznacza zatem to samo, co wyraża pojęcie „słownika” i „encyklopedii”.

W innym znaczeniu znajdujemy pojęcie „leksykon” w Stowniku języka polskiego, zgodnie z którym „leksykon” to „słownik o charakterze encyklopedycznym" [Szkiłądź, Bik, Pakosz, i in. 1982a, 22]. Znaczenie pojęcia „leksykon” zostało zawężone. Nie każdy słownik jest zatem jednocześnie leksykonem, lecz jedynie ten, który posiada encyklopedyczny charakter. Różnica między słownikiem a leksykonem dotyczy jego encyklopedycznego charakteru. „Słownik” podobnie jak „leksykon” może oznaczać określony zasób wyrazów, ogólnie słownictwo (np. mieć ubogi słownik). W powszechnie stosowanym znaczeniu na określenie jakiegoś zasobu słów oznacza „zbiór wyrazów ułożonych i opracowanych według pewnej zasady, zwykle alfabetycznie, najczęściej objaśnianych pod względem znaczeniowym i ilustrowanych przykładami użycia" [Szkiłądź, Bik, Pakosz, i in. 1982b, 257]. Istotą opracowania słownikowego jest zatem podanie znaczenia słów w ich etymologicznym pochodzeniu, frazeologicznym użyciu, ortograficznych prawidłowościach, itp. Zamieszczenie wyrazów, w tym pojęcia (hasła) „prawo kanoniczne" w opracowaniu określonym mianem słownika powinno odnosić się do wyjaśnienia tego pojęcia w różnych kontekstach i możliwościach. Słownik prawa kanonicznego funkcjonuje podobnie jak słownik chemiczny, biologiczny, matematyczny, psychologiczny, itp. Jego podstawową cechą powinno być podanie znaczenia poszczególnych pojęć występujących w ramach kościelnego porządku prawnego, w tym przede wszystkim podstawowego pojęcia, którym jest „prawo kanoniczne”, czyli jego właściwe określenie, rozumienie czy ewentualnie definicja.

Encyklopedia oznacza „dzieło obejmujące zbiór wiadomości (w hasłach ułożonych alfabetycznie lub według zagadnień) ze wszystkich dziedzin wiedzy lub jednej dyscypliny”. Pojęcie encyklopedii dotyczy zatem zasobu wiedzy (zbiór wiadomości), która może być przedstawiona w sposób hasłowy 
lub też opisowy ${ }^{1}$. Leksykon będący encyklopedycznym słownikiem wykracza poza przedstawienie znaczenia słów w ich historycznym i aktualnym znaczeniu. Łączy w sobie systematyczny układ hasłowy według przyjętego kryterium (np. alfabetycznie) wraz z zasobem wiedzy, która pozwala nie tylko zrozumieć pojęcie, ale odnaleźć znaczenie jego desygnatów.

Z powyższego przedstawienia wynika, że w słowniku prawa kanonicznego powinno zawierać się krótkie określenie znaczenia pojęcia prawo kanonicze. W pozostałych publikacjach o charakterze leksykalnym czy encyklopedycznym wiedza w nich przedstawiona powinna być znacznie szersza i bardziej dogłębna, która nie zadowala się jedynie określeniem znaczenia samego pojęcia, lecz ukazuje zjawisko w szerszym kontekście.

\section{PRAWO KANONICZNE W PUBLIKACJACH ENCYKLOPEDYCZNYCH}

Zapoznając się z hasłem „prawo kanoniczne” w jednotomowej Wielkiej Encyklopedii Prawa [Matwiejuk 2000, 736] oraz z hasłem „prawo wewnętrzne związków wyznaniowych" [Pietrzak 2000, 736] można dojść do przekonania, że przytoczone określenie wskazuje jedynie na prawo, które obowiązuje w związkach wyznaniowych. W przypadku pierwszego hasła mamy do czynienia ze stwierdzeniem, że jest to prawo obowiązujące w Kościele katolickim i w Kościele prawosławnym odpowiednio zebrane czy to w Kodeksie Prawa Kanonicznego z 1983 r. czy też wynikające z kanonów uchwalonych na soborach tak powszechnych, jak i lokalnych oraz z Kanonów Apostolskich. Jak na encyklopedyczną zawartość opracowania wyjaśnienie prawa kanonicznego niczego nie wyjaśnia. Podana została słownikowa informacja dotycząca prawa, którego nazwa funkcjonuje w przytoczonych Kościołach. Dodatkowa informacja odnosi się do zbiorów aktów normatywnych. Czytelnik odnosi wrażenie, że prawo kościelne to statyczna rzeczywistość, o historycznym pochodzeniu mająca swe źródło w działalności ustawodawczej. Ponadto, o ile pojęcie prawa kanonicznego jest charakterystyczne dla Kościoła katolickiego, o tyle Kościół prawosławny odwołuje się do pojęcia kanonów, co wskazuje na inne ujęcie rozumienia zjawiska prawnego wewnątrz obu Kościołów. Poprzez odniesienie do dru-

\footnotetext{
${ }^{1} \mathrm{~W}$ takim znaczeniu pojęcie „encyklopedia” zostało użyte przez: Łopatka 1995.
} 
giego z przytaczanych powyżej haseł można wnioskować, że dla autorów opracowania pojęcie prawa kanonicznego jest bardzo szerokie i dotyczy prawa, którym kierują się pozostałe związki wyznaniowe, co w przypadku Kościołów protestanckich nie znajduje potwierdzenia. Zamiast wiedzy encyklopedycznej czytelnik otrzymuje słownikowe wyjaśnienie pojęcia, wskazujące jedynie na zjawisko nim określane i miejsce jego występowania. Takie wyjaśnienie jest nieprecyzyjne $\mathrm{z}$ punktu widzenia kanonisty czy też podejścia, które odwołuje się do badań nad zjawiskiem prawnym od wewnątrz, z punktu widzenia systemu prawnego. Pojęciowa transpozycyjność nie sprzyja rzetelności określeń, aczkolwiek wskazuje na powszechność pewnych ujęć i stereotypowych stwierdzeń. Wyjaśnienie pojęcia nie sięgnęło jego znaczenia. Jego desygnat został wskazany, ale pozostał niewytłumaczony.

W Stowniku prawa kanonicznego autor hasła wyjaśnia, że termin „prawo kanoniczne" występuje w podwójnym znaczeniu. Takie podejście odpowiada charakterowi opracowania, jakim jest słownik, który zawiera w sobie terminy i pojęcia z obszaru prawa kanonicznego, które w opracowaniu są wyjaśnione. Nie jest wymagane, by słownikowe opracowanie podawało więcej informacji. Takie powinny być zawarte w opracowaniach encyklopedycznych, także w ich formie leksykalnej. Przystępując do wyjaśnienia terminu wskazuje na jego podwójne znaczenie. Po pierwsze jest to system norm, które obowiązują w Kościele. Doprecyzowuje charakter owych norm wskazując, że są one oparte na przesłankach teologicznych, które z kolei mają swe źródło w Bożym Objawieniu i w woli kościelnych ustawodawców. Dodaje, że te normy są zawarte w aktach normatywnych i zwyczajach. Czy jest to stwierdzenie wystarczające? Niewiele różni się od tych, z którymi spotkaliśmy się w Wielkiej Encyklopedii Prawa. Dodatkowa informacja dotyczy tego, że normy owego systemu zawierają się nie tylko w wymienionych uprzednio aktach normatywnych (kodeks i zbiory kanonów), ale zawarte są również w innych aktach oraz w zwyczajach. Stwierdzenie dotyczące odniesienia owych norm do Objawienia precyzują ogólne stwierdzenia zamieszczone w Wielkiej Encyklopedii Prawa, w których również zostały wskazane związki pomiędzy prawem wewnętrznym związków wyznaniowych a zasadami wiary i doktryny religijnej. Wyjaśnienie drugiego znaczenia terminu „prawo kanoniczne” wskazuje na objęcie nim dyscypliny naukowej. „której przedmiotem są normy należące do systemu prawa kanonicznego". Z przedstawionego w ten sposób wyjaśnienia terminu prawa 
kanonicznego można wysnuć jeden podstawowy wniosek, że prawo kanoniczne czy to jako zjawisko, czy też jako dyscyplina naukowa związane jest z systemem norm. Pomijam te wnioski, które są niejako powtórzeniem poprzednich sformułowań, a mianowicie: w Kościele istnieje prawo (z dalszej części opracowania wynika, że chodzi autorowi o Kościół katolicki), które zwane jest prawem kanonicznym, i którego istnienie wykazuje związki z wiarą (Objawieniem) oraz jest dziełem działalności ustawodawczej. Sformułowanie wskazujące na związki prawa z Objawieniem i kościelnym prawodawcą jest niezbyt szczęśliwe, gdyż nieprecyzyjnie określa, czy prawo kanoniczne ma swoje źródło w Objawieniu i woli prawodawcy łącznie, czy też może istnieć jako wynikające $\mathrm{z}$ Objawienia i osobno $\mathrm{z}$ woli prawodawcy, co najczęściej przekłada się na stwierdzenie istnienia prawa Bożego i prawa czysto kościelnego (leges mere eclesiasticae) w ramach jednego systemu kanonicznego. Wobec tak postawionego problemu nurtujące zawsze pozostanie pytanie o podstawy tejże władzy i jej ostatecznej funkcji w Kościele, gdy posługuje się narzędziem, jakim jest prawo.

Leksykon Prawa Kanonicznego, jak wynika ze znaczenia publikacji słownikowej o charakterze encyklopedycznym stawia większe wymagania dla prezentowanych w nim haseł, terminów z zakresu prawa kanonicznego niż w przypadku poprzednio przedstawionego Stownika prawa kanonicznego. Objętość tej publikacji jest tego dowodem. Omawiane w niej hasła nie odnoszą się jedynie do wyjaśnienia terminów, ale wraz z nim przedstawiają rzeczywistość prawną bezpośrednio z nim połączoną. Należy zatem spodziewać się więcej informacji na dany temat i jednocześnie w miarę pełnej, aczkolwiek z pewnością nie wyczerpującej. Można jednak podchodzić do leksykalnych treści z nadzieją, że będą one stanowiły, jeśli nie wystarczające opracowanie, przynajmniej dobry punkt wyjściowy dla dalszych opracowań wskazując na możliwe kierunki poszukiwań. W omawianym Leksykonie „prawo kanoniczne” [Krukowski 2019, 2207] zostało określone jako „zbiór norm prawnych ustanowionych lub uznawanych przez władzę kościelną, regulujących stosunki w Kościele i relacje Kościoła z innymi społecznościami”. Drugie znaczenie terminu to „nauka o normach obowiązujących w Kościele”. W dalszej części opracowania autor sięga do etymologicznego ukształtowania się terminu prawo kanoniczne, poprzez który doprecyzowuje jego znaczenie. Czyni to jednak poprzez odwołanie się do pojęcia ustawy wskazując na różnice terminologiczne wynikające $\mathrm{z}$ ich zastosowania w porządku kościelnym (kanon) i państwowym (nomos). Pod- 
kreśla również zmianę akcentów w określaniu prawa kanonicznego przed i po II Soborze Watykańskim. Tym, co łączy oba określenia jest odwołanie się do pojęcia ustawy. Prawo kanoniczne definiowane jest w perspektywie ustawy. Różnica w podejściu dotyczy rozłożenia akcentów. Przed Soborem zwracano uwagę na elementy formalne Tomaszowej definicji ustawy jako rozporządzenie rozumu, po Soborze natomiast do głosu doszła oryginalność elementu materialnego, zawsze jednak ustawy, a nie prawa. Nowym elementem materialnym określenia miały być teologiczne treści, które istotnie wpływają na odróżnienie ustawy kanonicznej od państwowej. W dalszych wywodach czytelnik zapoznaje się z różnymi klasyfikacjami nie tyle prawa kanonicznego, co norm prawa kanonicznego według kryteriów, jakimi są: źródło powstania, autor i zakres obowiązywania, obrządek, czas powstania, przedmiot regulacji. Przyjmując, że mamy do czynienia z dwoma porządkami prawnymi: państwowym i kościelnym, o różnym pochodzeniu i charakterze więzów społecznych w nich istniejących, to poza wskazaniem na różnice materialne obu porządków określenie prawa w kościelnym porządku prawnym niewiele się różni od określenia w porządku państwowym. Poza tym prawo kanoniczne $\mathrm{w}$ ten sposób przedstawione zostało ukazane w funkcji istnienia najpierw norm prawnych, a następnie ustawy jako ich konsekwencja.

Ostatnią z omawianych publikacji jest kolejna Wielka Encyklopedia Prawa, której drugi tom został w całości poświęcony zagadnieniom prawa kanonicznego. W odróżnieniu od pierwszej z przedstawionych publikacji pod tym samym tytułem w obecnej autorami opracowań poszczególnych haseł są kanoniści. Ponadto zagadnieniom prawa kanonicznego został poświęcony cały drugi tom Encyklopedii. Nie jest tak obszerny pod względem ilości haseł, jak wspomniany Leksykon, ale warto dostrzec jego wartość ze względu na umiejscowienie tematyki prawa kanonicznego w szerokiej gamie zagadnień prawnych, którym zostały poświęcone pozostałe tomy opracowania. Encyklopedie i słowniki są ograniczone przez wydawców ilością znaków, które mogą być zastosowane przy omawianiu materiału, preferencjami redaktorów odpowiedzialnych za poszczególne tomy. Dokonywane wybory powinny jednak mieć na celu umiejętne wyodrębnienie tego, co najbardziej ważne w ogromie istniejących zagadnień i zadbanie o aspektowo szerokie ich zaprezentowanie bez skupiania się na wyborze preferowanej opcji. W takich opracowaniach chodzi bowiem o podanie pierwszych i pod- 
stawowych informacji na dany temat, których dobór nie powinien ograniczać możliwości dalszego zdobywania, w miarę wszechstronnej, wiedzy.

Autor hasła „prawo kanoniczne” [Gałkowski 2014, 158-61] przyjął odmienną perspektywę omówienia zagadnienia prawa kanonicznego niż przedstawieni wcześniej autorzy. Najpierw zwrócił uwagę na etymologiczne znaczenie pojęcia prawa kanonicznego podkreślając wynikające $\mathrm{z}$ tego konsekwencje, a mianowicie świadomość pierwszych gmin chrześcijańskich istniejącego w nich prawa, jego źródeł i odrębności od prawa państwowego. Tym samym wskazał na właściwe podejście metodologiczne do określenia prawa kanonicznego, które powinno dokonywać się wewnątrz wspólnoty, w której ono jest obecne. Niewłaściwe są określenia prawa kanonicznego adoptujące czy transponujące pojęcia w ich jednoznacznym i stałym rozumieniu $\mathrm{z}$ innych porządków prawnych na obszar prawa kanonicznego, czego nie ustrzegli się prawnicy niemieccy w XIX w. czy włoscy począwszy od lat 30-tych ubiegłego stulecia. Z powodu tej aktywności pojawiły się również $\mathrm{w}$ kręgach kanonistów próby określenia prawa kanonicznego, w których należało brać pod uwagę soborowe zalecenia, by mówiąc i nauczając o nim mieć przed oczyma tajemnicę Kościoła. Chodzi bowiem nie tyle o prawo w Kościele, co prawo Kościoła. Ponadto chodzi o prawo Kościoła nie w funkcji władzy ustawodawczej, lecz o rzeczywistość, która wynika z samej jego natury przyczyniając się wraz ze wszystkim, co w Kościele jest niezbędne do zbawienia dusz. Z powyższych racji niewłaściwe jest podawanie określenia prawa kanonicznego nie przyjmując w punkcie wyjścia natury Kościoła, a dalej świadomości prawnej jego członków. Określenie prawa kanonicznego powinno zatem uwzględniać poznawalną rzeczywistość Kościoła z jego elementami wskazującymi na istniejące i kształtujące się relacje o charakterze powinnościowym.

Metodologia przyjęta w określaniu prawa kanonicznego pozwoliła autorowi odejść od traktowania prawa kanonicznego w jego analogicznym odniesieniu do prawa państwowego i sięgniecie do świadomości chrześcijan kształtujących swoje relacje społeczne $\mathrm{w}$ oparciu o więzy istniejące we wspólnocie wiary. Po drugie w odniesieniu do prawa kanonicznego należy pozostawić poza nim to wszystko, co nie może mieć wpływu na jego określenie sugerując analogię czy podobieństwo do prawa państwowego o proweniencji pozytywistyczno-normatywnej, jak również należy wyjść poza kontekst rozważań o charakterze filozoficznym czy socjologicznym wskazującym na związek społeczności z prawem. Ostatecznie bowiem chodzi 
o prawo Kościoła określane mianem kanonicznego. Jest prawem kanonicznym dlatego, że jest prawem Kościoła, a nie dlatego, że jest prawem w Kościele. Dlatego określenie prawa kanonicznego musi koniecznościowo wynikać z poznania elementów prawnych kościelnej wspólnoty. Określenie tego prawa mieści się nie tyle w pierwszym członie sformułowania, czyli „prawo”, lecz w tym, co jest wyrażone jako „kościelne”. Jest prawem kanonicznym dlatego, że jest prawem Kościoła. W kościelnej wspólnocie należy zatem odnaleźć jej aspekty prawne, nie zaś przyglądać się jej w aspekcie prawnym jak każdej innej wspólnocie. Prawo kanoniczne jest bowiem prawnym wymiarem Kościoła, prawnym wymiarem jego wiary. Nie miejsce w tym momencie na długie wywody uzasadniające takie stwierdzenia czy dowodzenie ich słuszności. Chodzi jedynie o zaprezentowanie stanowisk określających główny i przewodni element encyklopedycznych opracowań poświęconych prawu kanonicznemu, by z kolei wyciągnąć kolejne wnioski.

\section{UWAGI KRYTYCZNE}

Prezentacja kluczowego pojęcia kanonistyki, jakim jest prawo kanoniczne nastręcza pewne trudności. Przez stulecia pojęcie prawa kanonicznego nie wymagało zdefiniowania. Uwaga była skoncentrowana przede wszystkim na jego aspektach apologetycznych, obronie jako charakterystycznego elementu kościelnej wspólnoty przed zakusami wyrażonymi w tezach Marsyliusza z Padwy (tylko państwo może tworzyć prawo), twierdzeniach protestanckich o sprzeczności natury prawa i natury Kościoła, tezach S. Puffendorfa o stowarzyszeniowym charakterze Kościoła. Kościelni myśliciele uzasadniając prawo do prawa w Kościele odwoływali się do argumentacji filozoficznych, socjologicznych, prawnych istniejących poza Kościołem i wskazujących na adekwatność państwa oraz prawa, by następnie poprzez analogię przenieść tę argumentację na wspólnotę kościelną. Nie dostrzegam argumentów przemawiających za podobnym postępowaniem $\mathrm{w}$ dzisiejszych próbach określenia prawa kanonicznego. Uzależnia bowiem rozumienie prawa kanonicznego od prawa państwowego, wskazując na różnicę poprzez doprecyzowanie, że obowiązuje ono w Kościele lub w innych związkach wyznaniowych jako prawo regulujące organizację i funkcjonowanie organów kościelnych [Pietrzak 2000, 754]. W tak przedstawione i zaapli- 
kowane do kościelnej wspólnoty rozumienie prawa, ona sam nic nowego nie wprowadza, a z drugiej strony doświadczenie prawa we wspólnocie kościelnej nie wskazuje na specyfikę kościelnej realizacji prawa w prawie wespół ze świecką [Sobański 2002, 30]. W odniesieniu do takiego podejścia nasuwają się dwie uwagi. Po pierwsze jest ono bardziej bliskie prawnikom świeckim, którzy ze względu na zasób wiedzy i metodologiczne narzędzia nie są w stanie przekroczyć granic stawianych przez rygorystyczne kryteria naukowe. Druga uwaga dotyczy kontekstu określania zjawisk i definiowania pojęć. Powinny się one dokonywać od wewnątrz, od środowiska, w którym one zaistniały i dalej się rozwijały. Właściwym środowiskiem dla prawa kanonicznego jest wspólnota kościelna, gdzie zalążkiem jej istnienia jest wyznawana wiara i społeczne konsekwencje z niej wynikające.

Powyższe uwagi powinny wydać się zbyteczne w odniesieniu do opracowań dotyczących pojęcia prawa kanonicznego przedstawionych przez kanonistów i zamieszczonych w dziełach z zakresu kanonistyki. Jednak i one również zawierają odniesienia do prawa państwowego czy ogólnie do prawa poprzez określanie prawa kanonicznego na wzór tego pierwszego jako koniecznego elementu składowego społeczności. Ujęcie kwestii prawa kanonicznego w ten sposób zbliża je do podejść protestanckich, zgodnie z którymi prawo w Kościele jest jedynie wynikiem układów społecznych. Odwołanie się do argumentacji wskazującej na specyfikę tego prawa mającego swe źródło w Objawieniu na nic się zdaje, gdy Objawienie jest prezentowane jako źródło norm.

Stwierdzenia dotyczące różnego określenia i rozumienia prawa kanonicznego nie mogą nie wziąć pod uwagę pewnych orientacji metodologicznych w podejściu do tego zagadnienia. Nie są one wzajemnie wykluczające. Uzupełniają się i dopełniają pod jednym warunkiem, którym jest jednoznaczna perspektywa punktu wyjścia. Nie jest nią na pierwszym miejscu prawo, co mogłoby sugerować pojęcie „prawo kanoniczne”, ale Kościół, którego struktura „prowokuje” istnienie w nim prawa. I dlatego nie jest to prawo, lecz prawo kościelne, tzn. prawo Kościoła. Elementów prawnych należy poszukiwać w więzach tworzonych przez wiarę, w relacjach konstytuujących Kościól, które następnie odzwierciedlają się w relacjach konstytutywnych. Prawo kościelne jest ujęciem nadprzyrodzonych struktur Kościoła i do nich powinna się odwoływać każda jego definicja w punkcie wyjścia [Sobański 1975, 9-15]. 
Do związku między prawem i Kościołem nawiązują określenia prawa kanonicznego zawarte w Stowniku czy Leksykonie. Ten związek realizuje się jednak poprzez więzy formalne istnienia prawa w społeczności kościelnej, tak jak w innych społecznościach. Są to bowiem normy (system norm) obowiązujących w Kościele. Autorzy opracowań starają się wskazać na głębszą zależność pomiędzy prawem a Kościołem, co jednak sprowadza się do stwierdzeń, że system norm jest „oparty na przesłankach teologicznych” [Sitarz 2004, 136] lub „prawo kanoniczne opiera się na przyjęciu aktem wiary prawdy teologicznej zawartej w Objawieniu" [Krukowski 2019, 2208]. Z takich stwierdzeń wynika, że prawo kanoniczne posiada jakieś swoje przesłanki o teologicznym charakterze, które jednak w dalszej części opracowania nie zostały wskazane. Trudno również na podstawie tego ogólnego sformułowania odczytać związek pomiędzy przesłanką a wyprowadzonym z niej wnioskiem. Rozumowanie przeprowadzone według metodologicznych rygorów same w sobie prawidłowe nie zawsze musi być prawdziwe. Przesłanki teologiczne znajdowały się również przy próbach uzasadniania prawa w Kościele w oparciu o sformułowane przez R. Bellarmina określenie Kościoła, kategorię Królestwa Bożego u G. Philipsa, dar łaski G. Söhngena, urząd kościelny K. Rahnera, dogmat Wcielenia H. Bariona, czy określenie Kościoła jako Ludu Bożego przez szkołę nawarryjską [Gerosa 2005, 88-90, 103-110]. Tym, co łączy powyższe koncepcje jest wskazanie na prawo kanoniczne jako konsekwencja pewnej rzeczywistości, która niejako wymusza zaistnienie prawa. Głębsza analiza i próba zrozumienia powyższych uzasadnień wskazuje jednak, że związek pomiędzy podstawą twierdzeń a wyprowadzonymi z nich wnioskami ma charakter bardziej powinnościowy niż koniecznościowy. Skoro istnieje taka rzeczywistość, to powinna z niej wynikać adekwatna konsekwencja. W argumentacji o charakterze koniecznościowym należy wskazać na nierozłączny związek dwóch rzeczywistości tworzących spójną całość w taki sposób, by możliwe było powiedzenie o niej w pełni uwzględniając zawsze współistniejące ze sobą elementy. Wyprowadzanie wniosków dotyczących prawa kanonicznego z teologicznych przesłanek czy teologicznych prawd przyjętych aktem wiary w jakiejś mierze uzasadnia prawo kościelne i coś o nim mówi, ale nie wskazuje na jego zakorzenienie $\mathrm{w}$ naturze Kościoła i tym samym jego uczestnictwo w misji zbawczej. Natomiast umiejscowienie prawa kanonicznego poza misją realizowaną w Kościele i przez Kościół prowadzi do do- 
strzegania w nim jedynie elementu życia społecznego oraz analogicznego odniesienia do prawa.

Prawo kanoniczne nie jest czymś dodanym do życia Kościoła. Nie jest również konieczną konsekwencją życia społecznego. W takim rozumieniu jego rolę można by sprowadzić do regulacji zachowań zewnętrznych zmierzających do stabilizacji życia społecznego przez jego organizację w wymiarze instytucjonalnym i społecznym oraz unikanie konfliktów. Byłoby czymś dodanym do Kościoła, a jako dodane mogłoby wskazywać na niewystarczalność tego, co w Kościele jest z woli jego Boskiego założyciela. Intuicyjnie tę prawdę wyraził dogmat Soboru Trydenckiego wskazujący, że Chrystus jest tak samo prawodawcą, jak i zbawcą [Baron i Pietras 2004, 314-15]. Jego wola prawodawcza nie jest konsekwencją woli zbawczej, lecz obie współistnieją w jednym zamyśle wobec kościelnej wspólnoty [Sobański 2001, 63-64].

Kolejna uwaga na marginesie określeń prawa kanonicznego w omawianych publikacjach encyklopedycznych dotyczy utożsamienia jurydyczności z normatywnością. Prawo kanoniczne jest określane jako zbiór norm prawnych czy system norm obowiązujących w Kościele. Z takich stwierdzeń wynika zatem, że normatywność jest elementem uprzednim w stosunku do jurydyczności, a ta druga nie istnieje inaczej, jak tylko w funkcji tej pierwszej. Ostatecznie prowadziłoby to do wniosku, że normatywność jest niezależna od jurydyczności, a dalej, do konsekwencji uzasadnień woluntarystycznych decyzji sprawczych określanych jako prawne. Jurydyczny charakter więzi społecznych w jego relacyjnym i powinnościowym wymiarze jest zabezpieczony przez normatywne rozwiązania. Reguły relacji powinnościowych są uprzednie $\mathrm{w}$ stosunku do norm, gdyż to one regulują pewien fenomen ( $w$ tym przypadku prawny), nadają mu obiektywną rozpoznawalność i akceptację [D’Agostino 1993, 11-12]. W odniesieniu do prawa kanonicznego reguły powinnościowych zachowań rzeczywiście odnajdujemy w wierze, w której prawo ma swój początek i uzasadnienie, a normy są racjonalną konkretyzacją reguł wiary. $\mathrm{Z}$ tego też względu greckie sformułowanie kanon było od samego początku tłumaczone jako regula ${ }^{2}$, a nie lex, by wskazać na specyfikę porządku chrześcijańskiego niezależnie od porządku prawa rzymskiego [Gałkowski 2020, 159-60]. Chrześcijanie mają

${ }^{2}$ Takie sformułowanie znajduje się w Ga 6,15-16. Św. Paweł wskazuje na zasady (reguły) życia chrześcijańskiego i życzy pokoju oraz miłosierdzia w ten sposób postępującym. 
swoje własne prawo, które nie jest wynikiem woli rozrządzającej, lecz konsekwencją przyjętej wiary, która tworzy relacje społeczne o powinnościowym charakterze regulującym wzajemne odniesienia we wspólnocie.

\section{DEFINICJA I OKREŚLENIE}

Opracowania słownikowe o charakterze encyklopedycznym mają to do siebie, że skrótowo, a w miarę możliwości esencjonalnie, wyrażają treść terminu, który w nich jako jedno $\mathrm{z}$ haseł został zamieszczony. Często zawierają definicję, która jest wyjaśnieniem fenomenu określonego pojęciem. W przypadku określenia prawo kanoniczne podając to, czym jest na potrzeby słownikowego opracowania pojawiają się kwestie, które należy wziąć pod uwagę: 1) możliwość zdefiniowania prawa kanonicznego; 2) elementy konieczne do jego określenia.

Prawo kanoniczne jako termin oznacza fenomen istniejący w Kościele, a także naukę, która ten fenomen wyjaśnia. Naukowe opracowanie poprzedzone jest istnieniem wzbudzającego ciekawość przedmiotu zainteresowania, który najpierw musi zostać wyodrębniony spośród innych, odpowiednio określony, a następnie poddany intelektualnym analizom. Po określeniu przedmiotu można następnie precyzować punkt odniesienia (aspekt badawczy), określać metodę i dobierać narzędzia badawcze. Punktem wyjścia pozostaje zatem wspólnie określony fenomen, który staje się przedmiotem uzupełniających się wzajemnie zasobów wiedzy na jego temat. Różniące się określenia fenomenu nie sprzyjają prowadzeniu korelatywnych badań wielopłaszczyznowych. Taka sytuacja może zaistnieć również w przypadku prawa kanonicznego, jeśli zostanie ono określone jako prawo obowiązujące w Kościele. Rozważania dotyczące owego prawa będą obciążone niewystarczalnością graniczącą z niezrozumieniem, jeśli będą opierały się jedynie na analizie rzeczywistości zawartej w pojęciu prawa bez jej odniesienia do Kościoła. Prawo Kościoła ma to do siebie, że jego rozumienie uzależnione jest od specyficznej rzeczywistości Kościoła jako bosko-ludzkiej wspólnoty i jako takie może być poznawane jedynie $\mathrm{z}$ jej wnętrza. Poznanie Kościoła i prawa wzajemnie się warunkują, gdyż chodzi o Kościół w aspekcie prawnym, a nie o aspekty prawne Kościoła. Takie podejście wskazuje na niewystarczalność sformułowania definicji prawa kościelnego w oparciu o jej tradycyjne rozumienie. Definicja jest bowiem 
„wyjaśnieniem znaczenia jakiegoś wyrażenia [...] polegającym na podaniu dla tego wyrażenia jego równoznacznika" [Gregorowicz 1995, 32] ${ }^{3}$. W klasycznym rozumieniu definiowanie polega na podaniu treści danej nazwy poprzez określenie w definiensie zwrotu zakresowo nadrzędnego dla definiowanej nazwy przy jednoczesnym podaniu cech, które stanowią różnicę gatunkową pozwalającą na wskazanie desygnatów danej nazwy jako gatunek w stosunku do rodzaju [Zieliński 2012, 206]. Trudnością w podaniu definicji prawa kanonicznego w jej klasycznym rozumieniu jest właściwe określenie rodzaju, w odniesieniu do którego należałoby poszukiwać cech gatunkowych. Wynika to przede wszystkim z określenia prawa kanonicznego zawierającego w sobie dwa nierozłączne elementy, jakimi są prawo i Kościół współtworzące rzeczywistość określaną jako prawo kanoniczne. Gdyby bowiem przyjąć, że rodzajem tym jest zdefiniowany termin prawo, to od razu pojawiają się trudności związane $\mathrm{z}$ jednoznacznym zdefiniowaniem tego, co zawarte jest w zwrocie określającym zjawisko. Dodatkowa trudność wynika $\mathrm{z}$ faktu, że definiowanie prawa bierze pod uwagę rodzaj stosunków mających jurydyczną specyfikę, które w społeczności kościelnej posiadają zupełnie inne źródło niż w innych bytach społecznych. Gdyby nawet przyjąć taką perspektywę prób zdefiniowania prawa kościelnego to ostateczny rezultat wskazujący na gatunkową różnicę dotyczącą jedynie obszaru, do którego owe stosunki się odnoszą wskazywałby na analogiczne rozumienie prawa kościelnego. Byłoby ono jedynie prawem na wzór prawa obowiązującego chociażby w społecznościach państwowych i można byłoby o nim mówić podobnie, ze wskazaniem tylko na różnice o charakterze terytorialnym czy personalnym, jak o prawie państwowym. W ten sposób prawo kanoniczne zostało zaprezentowane $\mathrm{w}$ omawianych dotychczas publikacjach encyklopedycznych. Prawo kanoniczne to prawo obowiązujące w Kościele, analogicznie do prawa państwowego obowiązującego w konkretnych państwach. Jedyna różnica pomiędzy prawem kościelnym a prawem społeczności cywilnej dotyczyłaby kościelnego charakteru ustawodawcy.

W określeniu prawa kanonicznego słuszne jest podejście, w którym punkt wyjścia stanowi jego rozumienie i określenie istniejące w świadomości wspólnoty kościelnej ukształtowane pod wpływem relacji powinnościowych istniejących wewnątrz tej bosko-ludzkiej wspólnoty. Źródłem tych

\footnotetext{
${ }^{3}$ Dla potrzeb niniejszego przedłożenia nie jest konieczne rozróżnienie na definicję nominalną i realną.
} 
relacji jest wiara, która w chrześcijaństwie ma wymiar społeczny. Człowiek przyjmujący wiarę staje się w Kościele podmiotem praw i obowiązków. Z tego powodu relacje powinnościowe tworzone przez wiernych zawierają $\mathrm{w}$ sobie koniecznościowe odniesienie do dawcy powołania jako tego, który jest nieustannie obecny $\mathrm{w}$ decyzjach powinnościowych względem każdego członka tej samej wspólnoty. Prawo w Kościele nie jest produktem życia społecznego, lecz to prawny wymiar wiary do takiej formy życia doprowadza. Wspólnota ze wszystkimi jej wewnętrznymi atrybutami staje się darem i jednocześnie jest zadaniem jego realizacji.

Sformułowanie definicji prawa kanonicznego w jej klasycznym rozumieniu jest trudne czy wręcz niemożliwe. Zakłada bowiem wskazanie na istotne cechy, które odróżniają to prawo od jakichkolwiek innych określeń stosowanych do prawa. W zależności od tego, od czego prawo kanoniczne powinno się wyróżniać w swojej specyfice, ujmowane mogą być jego cechy, które będą jedynie wybiórczo traktowane, gdyż będą istniały jedynie w funkcji odróżniającej. Bogactwo prawa kanonicznego wyrażające się w jego określeniu nie powinno być określane w perspektywie różnic, lecz w swej istocie gwarantującej samodzielność zjawiska we wspólnocie, w której więzi społeczne wykraczają poza naturalne odniesienia. W tej perspektywie właściwym podejściem jest określenie tego, czym prawo kościelne jest, a jego cechy charakterystyczne powinny to prawo odróżniać od innych kościelnych fenomenów, z którymi tworzą jedną rzeczywistość zbawczą. Dlatego też słusznym jest podanie tych elementów, które charakteryzują prawo w Kościele jako prawo kościelne, a mianowicie jego transcendentalne odniesienie, eklezjalne zakorzenienie, specyfika stosunków społecznych oraz ich podmiot, którym jest człowiek ochrzczony [Sobański 2001, 51-55].

\section{PODSUMOWANIE}

Cechą encyklopedycznych publikacji jest podanie zwięzłych, ale i jednocześnie w miarę wyraźnych i jednoznacznych informacji na temat objętych przedmiotowym zainteresowaniem rzeczywistości przedstawionych pojęciowo $\mathrm{w}$ postaci haseł. Ich celem nie jest bowiem jedynie stwierdzenie istnienia pewnej rzeczywistości wyrażonej pojęciowo, ale określenie czy też zdefiniowanie tego, co dane pojęcie wyraża. W przypadku prawa kanonicznego różne sposoby jego określania wskazują na pewne orientacje upra- 
wiania kanonistyki i w zależności od sposobów podejścia określone aspekty przedmiotu zainteresowań będą bardziej lub mniej eksponowane. Uważam jednak, że właściwe określenie przedmiotu badawczych zainteresowań stanowi punkt wyjścia dla dalszego wyboru aspektów właściwego do niego podejścia.

\section{PIŚMIENNICTWO}

Bańko, Mirosław, red. 2005. Wielki stownik wyrazów bliskoznacznych. Warszawa: Wydawnictwo Naukowe PWN.

Baron, Arkadiusz, i Henryk Pietras, red. 2004. Dokumenty Soborów Powszechnych. Tekst łaciński i polski. T. 4 (1511-1870). Kraków: Wydawnictwo WAM. Księża Jezuici.

D’Agostino, Francesco. 1993. Filosofia del diritto. Torino: G. Giappichelli Editore.

Gałkowski, Tomasz. 2014. „Prawo kanoniczne (prawo kościelne).” W Wielka Encyklopedia Prawa. T. 2: Prawo kanoniczne, red. Grzegorz Leszczyński, 158-61. Warszawa: Fundacja „Ubi societas, ibi ius”.

Gałkowski, Tomasz. 2020. Ogólne zasady prawa w prawie kanonicznym. Warszawa: Wydawnictwo Naukowe UKSW.

Gerosa, Libero. 2005. Teologia del diritto canonico: fondamenti storici e sviluppi sistematici. Lugano-Varese: EUPRESS FTL.

Gregorowicz, Jan. 1995. Zarys logiki dla prawników. Łódź: Wydawnictwo Grand Gamma.

Krukowski, Józef. 2019. „Prawo kanoniczne.” W Leksykon Prawa Kanonicznego, red. Mirosław Sitarz, 2207-211. Lublin: Stowarzyszenie Absolwentów i Przyjaciół Wydziału Prawa Katolickiego Uniwersytetu Lubelskiego.

Leszczyński, Grzegorz, red. 2014. Wielka Encyklopedia Prawa. T. 2: Prawo kanoniczne. Warszawa: Fundacja „Ubi societas, ibi ius”.

Łopatka, Adam. 1995. Encyklopedia prawa. Warszawa: Wydawnictwa Prywatnej Wyższej Szkoły Businessu i Administracji.

Matwiejuk, Jarosław. 2000. „Prawo kanoniczne.” W Wielka Encyklopedia Prawa, red. Eugeniusz Smoktunowicz, i Cezary Kosikowski, 736. Białystok-Warszawa: Wydawnictwo Prawo i Praktyka Gospodarcza.

Pietrzak, Michał. 2000. „Prawo wewnętrzne związków wyznaniowych.” W Wielka Encyklopedia Prawa, red. Eugeniusz Smoktunowicz, i Cezary Kosikowski, 754. Białystok-Warszawa: Wydawnictwo Prawo i Praktyka Gospodarcza.

Sitarz, Mirosław. 2004. Stownik Prawa Kanonicznego. Warszawa: Instytut Wydawniczy Pax.

Sitarz, Mirosław, red. 2019. Leksykon Prawa Kanonicznego. Lublin: Stowarzyszenie Absolwentów i Przyjaciół Wydziału Prawa Katolickiego Uniwersytetu Lubelskiego.

Smoktunowicz, Eugeniusz, i Cezary Kosikowski, red. 2000. Wielka Encyklopedia Prawa. Białystok-Warszawa: Wydawnictwo Prawo i Praktyka Gospodarcza. 
Sobański, Remigiusz. 1975. „Wprowadzenie do roli prawa w Kościele”. Prawo Kanoniczne 18, nr 1-2:3-23.

Sobański, Remigiusz. 2001. Nauki podstawowe prawa kanonicznego. T. 2: Teologia prawa kościelnego. Warszawa: Wydawnictwo UKSW.

Sobański, Remigiusz. 2002. „Kanonista na trzech wydziałach.” Prawo Kanoniczne 45, nr 1-2:21-31.

Szkiłądź, Hipolit, Stanisław Bik, Barbara Pakosz, i in., red. 1982a. Słownik języka polskiego, t. 2, 22. Warszawa: PWN.

Szkiłądź, Hipolit, Stanisław Bik, Barbara Pakosz, i in., red. 1982b. Słownik języka polskiego, t. 3, 257. Warszawa: PWN.

Zieliński, Maciej. 2012. Wykładnia prawa. Zasady, reguty, wskazówki. Warszawa: LexisNexis.

\title{
Definiowanie prawa kanonicznego
}

\begin{abstract}
Abstrakt
Punktem odniesienia dla przeprowadzonych rozważań są określenia prawa kanonicznego, które zostały zawarte w czterech polskich publikacjach o charakterze encyklopedycznym. Trzy z nich dotyczą prawa kanonicznego, a jedna została poświęcona prawu. W niej również zostało zawarte hasło „prawo kanoniczne”. Autor prezentuje poszczególne omówienia zagadnienia prawa kanonicznego koncentrując swoją uwagę wokół rozumienia i określania prawa kanonicznego. Wskazuje na różnice w podejściu do zagadnienia pomiędzy prawnikami a kanonistami, w ujęciu których prawo kanoniczne posiada swoje teologiczne implikacje. Dostrzega również istniejące różnice w określeniu prawa kanonicznego, na które znaczny wpływ posiadają orientacje uprawiania kanonistyki przez autorów poszczególnych opracowań. Wysuwa wniosek, że wieloaspektowe podejście do badań nad prawem kanonicznym powinno w punkcie wyjścia mieć jasno określony przedmiot naukowych badań i rozstrzygnięć. W tym kontekście zastanawia się nad możliwością podania definicji prawa kanonicznego w jej klasycznym rozumieniu. Skłania się ku stwierdzeniu takiej niemożliwości. W zamian zwraca uwagę na konieczność wyodrębnienia tych elementów kościelnej struktury i stosunków społecznych, dzięki którym istnieje możliwość określenia prawa kanonicznego.
\end{abstract}

Słowa kluczowe: Kościół; prawo; encyklopedia; słownik; leksykon; definicja

\section{Defining Canon Law}

\section{Abstract}

The point of reference for the considerations are the definitions of canon law, which were included in four Polish encyclopedic publications. Three of them concern canon law and one is focused on law. It also contained the formulation "canon law." The author presents individual discussions on the issues of canon law, focusing his attention 
on understanding and defining it. He points to the differences in the approach to the issue between lawyers and canonists, from whose point of view canon law has its theological implications. He also notices the existing differences in the definition of canon law, which are significantly influenced by the orientation in which the authors of individual studies practice canon studies. He concludes that a multifaceted approach to the study of canon law should, as a starting point, measure a clearly defined subject of scientific research and solutions. In this context, he considers the possibility of giving a definition of canon law in its classic sense. He is inclined to assert such an impossibility. Instead, it draws attention to the need to distinguish those elements of the church structure and social relations, thanks to which it is possible to define canon law.

Keywords: Church; law; encyclopedia; dictionary; lexicon; definition

Information about Author: DR. HABIL. TOMASZ GAŁKOWSKI CP, UNIVERSITY PROFESSOR - Department of History, Theory and General Norms of Canon Law, Faculty of Canon Law, The Cardinal Stefan Wyszyński University in Warsaw; correspondence address: ul. Dewajtis 5, 01-815 Warszawa, Poland; e-mail: t.galkowski@uksw.edu.pl; https://orcid.org/0000-0001-9166-9516 